\title{
Facilitating community building in Learning Networks through peer tutoring in ad hoc transient communities
}

Citation for published version (APA):

Kester, L., Sloep, P., Van Rosmalen, P., Brouns, F., Koné, M., \& Koper, R. (2007). Facilitating community building in Learning Networks through peer tutoring in ad hoc transient communities. International Journal of Web Based Communities, 3(2), 198-205. https://doi.org/10.1504/IJWBC.2007.014080

DOI:

10.1504/IJWBC.2007.014080

Document status and date:

Published: 18/04/2007

Document Version:

Peer reviewed version

Please check the document version of this publication:

- A submitted manuscript is the version of the article upon submission and before peer-review. There can be important differences between the submitted version and the official published version of record. People interested in the research are advised to contact the author for the final version of the publication, or visit the DOI to the publisher's website.

- The final author version and the galley proof are versions of the publication after peer review.

- The final published version features the final layout of the paper including the volume, issue and page numbers.

Link to publication

\section{General rights}

Copyright and moral rights for the publications made accessible in the public portal are retained by the authors and/or other copyright owners and it is a condition of accessing publications that users recognise and abide by the legal requirements associated with these rights.

- Users may download and print one copy of any publication from the public portal for the purpose of private study or research.

- You may not further distribute the material or use it for any profit-making activity or commercial gain

- You may freely distribute the URL identifying the publication in the public portal.

If the publication is distributed under the terms of Article 25fa of the Dutch Copyright Act, indicated by the "Taverne" license above, please follow below link for the End User Agreement:

https://www.ou.nl/taverne-agreement

Take down policy

If you believe that this document breaches copyright please contact us at:

pure-support@ou.nl

providing details and we will investigate your claim.

Downloaded from https://research.ou.nl/ on date: 26 Apr. 2023 


\section{Facilitating community building in Learning Networks through peer tutoring in ad hoc transient communities}

Liesbeth Kester, Peter B. Sloep, Peter van Rosmalen, Francis Brouns, Malik Koné, Rob Koper

Open Universiteit Nederland

preprint

please do not quote or distribute 
Title: Facilitating community building in Learning Networks through peer tutoring in ad hoc transient communities

Authors: Liesbeth Kester, Peter B. Sloep, Peter van Rosmalen, Francis Brouns, Malik Koné, Rob Koper

Affiliation for all authors:
Educational Technology Expertise Centre
Open University of the Netherlands
PO Box 29606401 DL Heerlen
The Netherlands
fax +31455722800

email addresses: liesbeth.kester@ou.nl peter.sloep@ou.nl peter.vanrosmalen@ou.nl francis.brouns@ou.nl malik.kone@ou.nl rob.koper@ou.nl

\begin{abstract}
Learning in a so called Learning Network is particularly attractive to selfdirected learners, who themselves decide on their learning program as well as on the timing, pace and place of their studies. However, such learners may easily become isolated, which is detrimental to their studies. Furthermore, supporting them with their studies rapidly lead to staff overload. This paper discusses of ad hoc, transient communities as a means of tackling both problems. It is argued that such communities are well poised to enhance the sociability of a Learning Network and increase learning effectiveness.
\end{abstract}

Keywords: learning networks, peer tutoring, community building, self-directed learners.

\title{
Bibliographical Notes:
}

Liesbeth Kester is an assistant professor at the Open University of the Netherlands Educational Technology Expertise Centre. After her study Psychology at the University of Amsterdam (MA 1997), she received her PhD from the Open University of the Netherlands and has been working there ever since. She is involved in research and development of effective and efficient e-learning environments that support life-long learning. Her research interests include social support strategies and content-related support tools that foster self-directed learning.

Peter B. Sloep is an associate professor at the Open University of the Netherlands Educational Technology Expertise Centre and Fontys University of Applied Sciences School of Education. He studied biology at the Free University of Amsterdam (MSc 1978) and received his PhD from the University of Groningen (1983). Since then he has worked at the Open University, first as a course developer, later to turn his attention to educational technology. His research interest include the technical affordances including specifications for interoperability - and social affordances - including social software - that are conducive to self-directed learning. See for a list of publications: <http://www.ou.nl/open/psl/cv.html>

Peter van Rosmalen has been active in educational technology since the early eighties both as consultant and in a variety of research projects around authoring tools, simulations, computer supported cooperative learning and knowledge management. In 2000 he was co-founder and director of a company in e-learning and knowledge management. Since 2003 he has been researcher at ETEC. His research focuses on the use of agents in electronic learning environments, in particular how agents can help tutors to establish effective and efficient learning related interactions without increasing 
their workload.

Francis Brouns graduated in Biology from Wageningen University and obtained a PhD in Agriculture at the University of Aberdeen. After returning to The Netherlands she worked for an international association for distance learning. After that she moved to the Open University of the Netherlands as ICT Developer. The main activities are in development of innovative e-learning environments, with focus on new educational and ICT technologies, standards, development of the IMS LD specification, and the application of new technologies to create efficient and effective learning environments.

Malik Koné studied computer science, mathematics, and cognitive sciences (Artificial intelligence, psychology) at Grenoble University. He graduated with Bachelor in applied mathematics to social sciences. In 2004, he finished his master program in didactic sciences and computer supported learning, for which he worked on several projects, including the creation of software to generate networks with social network structure similarities. He currently works on a PhD on knowledge distribution in social networks, especially on tools that build up and modify virtual communities so as to enhance knowledge dissemination throughout the entire community.

Rob Koper is professor and director of learning technologies research at the Open University of the Netherlands. In this research we study and develop models and technologies to support the sharing of knowledge and learning resources in learning networks. This includes work on software agents, competence interoperability, learning design tools and social exchange mechanisms. He has more than 20 years of experience in the field and has (had) numerous roles in editorial boards, conference committees, management and advisory boards, etc. He was - among other things - responsible for the development of Educational Modelling Language (EML), currently an open standard through the IMS consortium (IMS Learning Design) 
The term 'community' in relation to professionals ('community of practice') and learners ('learning community') is used widely and, it seems, not always with due care: one gets the impression that such communities can be created at will by any sufficiently persistent designer, be it a knowledge manager or teacher. As Barab, Kling et al. (2004) have pointed out clearly, this is a mistake. To avoid falling in this trap we adopted the term 'Learning Network', which we define as an ensemble of people, institutions and learning resources which are mutually connected through and supported by information and communication technologies such that the network self-organizes to gives rise to effective, efficient and attractive lifelong learning. A Learning Network thus is a mere incipient community. Importantly also, a Learning Networks takes the self-directedness of the learner as its starting point, rather than as an element in a design based on particular instructional principles (Squires, 1999). This is why learners are allowed to create their own learning activities and learning plans, and share them with peers and institutions (Koper and Sloep, 2002; Koper et al, 2005.

Learning Networks thus conceived are not without problems. Without a proper supportstructure, learner self-directedness easily degrades into learner isolation. Learners who do not feel socially embedded will not flourish, to the detriment of their academic achievements and their perception of academic life. In general, individual success or failure on a learning activity depends on the extent to which learners perceive themselves as participants of a community (Wegerif, 1998). Self-directed learners are also likely to make extensive demands on tutors as their collective heterogeneity will lead to a great variety of tutoring requests. This tends to increase the tutor workload. (Romiszowski and Ravitz, 1997 fide Fox and MacKeogh, 2003; Rumble, 2001). According to De Vries, et al. (2005) teachers in online and blended learning environments consider initiating, receiving and answering questions of students time-consuming. Hence, for 
Learning Networks to be successful learning communities, it is imperative to implement techniques that enhance a student's learning process and yet do not increase the workload of tutors (Fox and MacKeogh, 2003).

In this paper, we propose that peer tutoring in ad hoc transient communities will both enhance the social embedding of learners in a Learning Network and keep the tutor load within bounds. Peer tutoring is a form of cooperative learning (Griffin and Griffin, 1998), the term ad hoc transient community we coined ourselves to denote smaller communities within a larger whole that fulfil a specific learning related goal and exist for a limited period of time (more on this later). To make our case, we first identify six generally desirable characteristics of community building and peer tutoring. We then detail our proposal for community building though peer tutoring in ad hoc transient communities. To assess the value of our proposal, we discuss to what extent it fits the desirable characteristics of community learning and peer tutoring.

\section{$2 \quad$ Learning Communities and Peer Tutoring}

\subsection{Learning Communities}

According to Wenger and collaborators (2002), learning communities are groups of people who acquire new knowledge through cooperation and collaboration. To meet with success, a learning community depends on its social space, its member characteristics, and the characteristics of the community as a whole. An effective social space is characterised by affective work relationships, strong group cohesiveness, trust, respect, belonging and satisfaction (Kreijns, 2004; Nichani, 2001; Rovai, 2002). Through social interaction social spaces emerge. Social interaction occurs if learners: (i) are likely to meet again in the future (continuity), (ii) are able to identify each other (recognisability) and (iii) know how any other person has behaved in the past (history). If individuals seldom meet, they are very much tempted to behave selfishly. This also occurs if 
individuals are not identifiable and no history of a person's behaviour is available (Kollock, 1998).

The characteristics of the people in the community matter too. First, people differ with regard to their experience with communities. Often, students are divided in veterans and 'newbies'. According to Brown (2001), veterans show good community behaviour. They are supportive, encourage peers, share knowledge and experiences, reflect on past learning, and sustain friendships and/or acquaintances begun earlier. Newbies depend much less on other group members and are reluctant to invoke tutor help. Veterans are inclined to do their 'duty' in the beginning but after a while tend to restrict their communication to veterans only. This hinders community building (Brown, 2001). Veterans therefore need incentives to continue to interact with newbies.

Second, most people are trend-followers; however, it is the trendsetters that make the difference. Nichani (2001) describes three types of trendsetters: connectors, mavens and salesmen. Connectors form the 'social glue' of a community; they are very sociable and attentive and have a talent for making friends. Mavens are the information experts who collect information and tell others about it. Salesmen are persuaders, they are inclined to reach out to the unconvinced and persuade them to join the community. Finally, according to Preece et al. (2004) participants of online newsgroups differ in their inclination to either lurk or post in a community. Lurkers belong to a community but never post in it. Posters and lurkers are attracted to a community for the same reasons. However, posters feel their needs are better met, perceive more benefit and feel a greater sense of membership than lurkers. Posters do not necessarily regard lurkers as inferior members. But both Preece and Weber agree that without a critical mass of posters, no community will ever thrive (Preece et al., 2004; Weber, 2004). 
Communities are characterised by boundaries, rules, monitoring possibilities and sanctioning mechanisms (Kollock and Smith, 1996; Koper, et al., 2004). By means of clearly defined boundaries, communities protect the collective good to outsiders and encourage ongoing interaction. Communities also have a set of rules that govern the use of common resources and point out who is responsible for producing and maintaining the collective goods. By monitoring each other's actions in a community, community members see whether their fellow members comply with these rules. Aberrant behaviour is mostly controlled by informal mechanism but sometimes more firm measures, as severe as banishment from the group, are taken. So, monitoring and sanctioning are important facilitators of cooperative relations (Kollock and Smidt, 1996).

\subsection{Peer Tutoring}

Fox and MacKeogh (2003) compared peer tutoring to face-to-face tutoring. According to their findings, online tutors do not necessarily spend more time on tutoring than face-toface tutors. More importantly, both groups achieved the same learning outcomes. Peer tutoring, furthermore, has the beneficial effect that it provides learners with a reciprocal social support system (Fantuzzo et al., 1989). Academic productivity peaks when the performance of group members is transparent and quantifiable to all other group members (Slavin, 1995). Also, learners who engage in peer tutoring are more satisfied with academic life; they are more intrinsically motivated and more engaged with the learning environment; they perceive their learning experience more positively, and experience less task-related anxiety (Fantuzzo et al., 1989). Finally, the co-operative process stimulates reflection; the peer interaction improves self-esteem and commitment to work as well as a sense of belonging (Anderson et al., 2000).

As a further beneficial effect, peer tutoring may also enhance learning or knowledge construction (Fantuzzo, et al., 1989; Gyanani and Pahuja, 1995; King et al., 1998; Wong 
et al., 2003). Interestingly, tutors prove to benefit more from peer tutoring than do tutees, presumably because they engage in such activities as preparing to teach and, most importantly, actually to teach (Fantuzzo, et al., 1989).

\section{Peer Tutoring in Ad Hoc Transient Communities}

To implement the above recommendations in the context of Learning Networks, we develop the notion of an ad hoc transient community. Any such community is a subset of the larger Learning Network; it is brought into existence to fulfil a particular request (its ad hoc-ness) and exists for a limited period of time only (its transience). Requests for support may range from requests for support with the learning content or the learning processes, demands for information regarding administrative matters, requests for

additional learning materials, to requests for (peer-)assessment of (De Vries et al., 2005). In this paper, we focus on peer-tutoring; however most of what we claim equally well applies - mutatis mutandis - to others kinds of questions.

An ad hoc transient community always starts with some learner who has a specific request and thus adopts the role of tutee. Depending on the nature of the request, peers have to be found that are suitable for the peer tutor role. Thus a mechanism is needed to populate the ad hoc transient community with actual people. To do this one has to determine whether a candidate peer tutor:

- Has sufficient mastery of the content to answer the question (content competency)

- Is sufficiently competent to support the tutee (tutor competency)?

- Is eligible to answer the content question (tutor eligibility)?

- Is available to support the tutee within an acceptable timeframe (tutor availability)? Content competency reflects the peer tutor's mastery of the content relevant for the content question. A digital portfolio or learner dossier can be used to determine this. Tutor competency refers to the ability of a peer tutor satisfactorily to support peers who 
have questions with regard to content. This information could be acquired by keeping track of a user's tutoring history and by letting tutees rate peer tutors' past performance. When acquiring tutors, one should make sure to mix inexperienced, lowscoring tutors, with experienced, high-scoring ones. The content competency of a learner in a Learning Network should be visible to all members of the ad hoc transient community to assure individual accountability (Slavin, 1995). Tutor eligibility, furthermore, is an important factor in spreading tutor responsibilities over all learners. If content and tutor competency were to be the only factors to decide who becomes a member of an ad hoc transient community, some peers will easily become overloaded whilst others will never be involved: Those who participate often are likely to become better tutors, and, assuming a roughly hierarchical organization of content, those who have progressed further will be able to answer more questions than those who have just started. To avoid this undesirable effect, only those tutors should be eligible who are in terms of content competence close to the tutee. Finally, tutor availability refers to such practical issues as actual short-term presence in the Learning Network (avoiding absence due to holidays, days off, illness, et cetera), or workload (i.e., studying for exams, past participation in the communities).

Once the peer tutors have been identified, they should start working on the answer for the content question. This is an ill-structured, collaborative process that should encourage group members each equally to contribute to a final answer (Strijbos et al., 2004). Once the tutee is satisfied the ad hoc transient community has outlived its purpose and ceases to exist.

No technical tour de force is needed to set up and run an ad hoc transient community. To be able at all to populate such communities with Learning Network users, their characteristics need to be stored in a digital portfolio. A relatively simple computer 
program suffices to compute a Learning Network user's tutor suitability. Ideally also, when asked to answer a question, tutors should not have to start from scratch but be given proto-answers derived from existing text bodies. Proto-answers should be ranked for suitability, using language technologies such as Latent Semantic Analysis (Van Bruggen et al., 2004). Finally, a system should be available which offers tutee and tutors a collaborative workspace. It should be seeded with the proto-answers and, preferably, maintain a historical record of the changes that the participants have made. It should also be equipped with mechanisms that alert the participants to new contributions. Systems that combine the functionalities of a wiki, for collaboration, and a blog, for alerting through some kind of RSS-based mechanism, come close to meeting these criteria.

\section{Discussion}

In the above, we argued that the self-directedness of learners in a Learning Network creates two problems. First, in so far as self-directedness leads to isolation, it negatively affects their academic achievements; second, as self-directedness probably comes with heterogeneity it increases the workload of tutors. We proposed that peer tutoring in ad hoc, transient communities, which are part of a Learning Network, would solve these problems and we discussed various characteristics that such communities then should exhibit.

Recognisability of members can be guaranteed by banning the use screen names. A historical record of user actions can easily be maintained by logging all their actions, the most significant of which become part of the user's digital portfolio; continuity of contact can thus be promoted (1). A happy mix of connectors, mavens, and salesmen, follows from heterogeneity of the Learning Network as a whole; newbies and veterans can be made to participate in ad hoc transient communities by monitoring each learner's 
tutoring competency (2). The way an ad hoc transient community is formed, sets a clear boundary to it. Furthermore, it obviously operates according to a clear set of rules that, since they make up the design of any ad hoc transient community, are difficult to cheat on (3). By their very design, ad hoc transient communities spread tutor workload over peers (4). Because they require tutors to collaborate on answering the tutee's question, they facilitate engagement, commitment and a sense of belonging (5). Similarly, this collaboration will also promote higher-order, academic cognitive processes (6).

In conclusion, ad hoc transient communities fulfil some of the expectations because they are designed to do so. This applies to items 1, 2, and 3 in particular. For other expectations - items 4,5 and 6 - it is a priori likely that they will, but ultimately it is an empirical question whether they actually do. There is a literature on the notion of swift trust that lends support to item 5 (Meyerson et al. 1996; Coppola et al., 2004). However, for this and the other items only experiments can provide decisive answers.

\section{References}

Anderson, A., Cheyne, W., Foot, H., Howe, C., Low, J., and Tolmie, A. (2000) 'Computer support for peer-based methodology tutorials', Journal of Computer Assisted Learning, Vol. 16, pp. 41-53.

Barab, S. A., R. Kling, Gray, J.H., Eds. (2004) Designing for virtual communities in the service of learning, Cambridge University Press, Cambridge UK.

Brown, R. E. (2001) 'The process of community-building in distance learning classes', Journal of Ansynchronous Learning Networks, Vol. 5, No. 2, pp. 18-35. 
Coppola, N., Hiltz, S. R., and Rotter, N. (2004) 'Building Trust in Virtual Teams', IEEE Transactions on Professional Communication, Vol. 47, pp. 95-104.

De Vries, F., Kester, L., Sloep, P., Van Rosmalen, P., Pannekeet, K., and Koper, R. (2005) 'Identification of critical time-consuming student support activities that can be alleviated by technologies', Research in Learning Technology (ALT-J), Vol. 13, No. 3, pp. 219-229.

Fantuzzo, J. W., Riggio, R. E., Connelly, S., and Dimeff, L. A. (1989) 'Effects of reciprocal peer tutoring on academic achievement and psychological adjustment: A component analysis', Journal of Educational Psychology, Vol. 81, pp. 173-177.

Fox, S., and MacKeogh, K. (2003) 'Can elearning promote higher-order learning without tutor overload?', Open Learning, Vol. 18, No. 2, pp. 121-134.

Griffin, M. M., and Griffin, B. W. (1998) 'An investigation of the effects of reciprocal peer tutoring on achievement, self-efficacy, and test anxiety', Contemporary Educational Psychology, Vol. 23, pp. 298-311.

Gyanani, T. C., and Pahuja, P. (1995) 'Effects of peer tutoring on abilities and achievement', Contemporary Educational Psychology. Vol. 20, pp. 469-475.

Kollock, P. (1998) 'Design principles for online communities', PC Update, Vol. 15, No. 5, pp. 58-60.

Kollock, P. and Smith, M. (1996) 'Managing the virtual commons: Cooperation and conflict in computer communities', in Hering, S. (Ed.): Computer-mediated 
communication: Linguistic, social, and cross-cultural perspectives, John Benjamins, Amsterdam, pp. 109-128.

Koper, R., and Sloep, P. B (2002) Learning Networks connecting people, organizations, autonomous agents and learning resources to establish the emergence of effective lifelong learning. RTD Program into Learning Technologies 2003-2008. More is different in http://hdl.handle.net/1820/65 accessed 13 October 2006.

Koper, R., Rusman, E. and Sloep, P. (2005) 'Effective Learning Network', Lifelong Learning in Europe, Vol. IX, pp. 18-28.

Koper, R., Pannekeet, K., Hendriks, M., and Hummel, H. (2004) 'Building communities for the exchange of learning objects: theoretical foundations and requirements', ALT-J, Research in Learning Technology, Vol. 12, pp. 21-35.

Kreijns, K. (2004) Sociable CSCL environments. Social affordances, sociability, and social presence, Unpublished doctoral thesis, Open University of the Netherlands, Heerlen, The Netherlands.

Meyerson, D., Weick, K. E., and Kramer, R. M. (1996) 'Swift trust and temporary groups', in Kramer, R. M. and Tyler, T. R. (Eds): Trust in organizations: Frontiers of theory and research, Sage, Thousand Oaks, CA, pp. 166-195.

Nichani, M. (2001) 'Communities of practice at the core' in Elearningpost http://www.elearningpost.com/features/archives/002090.asp, accessed 13 October 2006. 
Preece, J., Nonneke, B., and Andrews, D. (2004) 'The top five reasons for lurking: Improving community experiences for everyone', Computers in Human Behavior, Vol. 20, pp. 201-223.

Romiszowski, A. and Ravitz, J. (1997) 'Computer Mediated Communications', in Romiszowski, A and Dills, C. (Eds): Instructional Development: State of the Art, Educational Technology Publications, Englewood Cliffs, NJ, pp. 745-768.

Rovai, A. P. (2002) 'Building a Sense of Community at a Distance' International Review of Research in Open and Distance Learning, Vol. 3, No. 1.

http://www.irrodl.org/content/v3.1/rovai.html, accessed 13 October 2006.

Rumble, G. (2001) 'The Costs and Costing of Networked Learning', Journal of Asynchronous Learning Networks Vol. 5, pp. 75-96.

Slavin, R. E. (1995) 'When does cooperative learning increase student achievement?', Psychological Bulletin, Vol. 94, pp. 429-445.

Squires, D. (1999) 'Educational Software and Learning: Subversive Use and Volatile Design', Proceedings of the 32nd Hawaii International Conference on System Sciences, pp. 1-6.

Strijbos, J. W., Martens, R. L., and Jochems, W. (2004) 'Designing for interaction: Six steps to designing computer-supported group-based learning', Computers and Education, Vol. 42, pp. 403-424.

Van Bruggen, J., Sloep, P., van Rosmalen, P., Brouns, F., Vogten, H., Koper, R., and 
Tattersall, C. (2004) 'Latent semantic analysis as a tool for learner positioning in learning networks for lifelong learning', British Journal of Educational Technology, Vol. 35, pp. 729-738.

Weber, S. (2004) The Success of Open Source, Harvard University Press, Cambridge, Ma.

Wegerif, R., Mercer, N., and Dawes, L. (1998) 'Software design to support discussion in the primary curriculum', Journal of Computer Assisted Learning, Vol. 14, pp. 199-211.

Wenger, E., McDermott, R., and Snyder, W. (2002) Cultivating Communities of Practice: a guide to managing knowledge, Harvard Business School Press, Cambridge, Ma.

Wong, W. K., Chan, T. W., Chou, C. Y., Heh, J. S., and Tung, S. H. (2003) 'Reciprocal tutoring using cognitive tools' Journal of Computer Assisted Learning, Vol. 19, pp. 416428. 